\title{
Catheter-induced coronary artery dissection: the role of exhalation during contrast medium injection
}

\author{
Andreas Y. Andreou \\ Department of Cardiology, Limassol General Hospital, Limassol, Cyprus
}

ARTICLE INFO

Article history:

Submitted: 1. 4. 2018

Accepted: 30. 6. 2018

Available online: 2. 10. 2019

Klíčová slova:

Disekce koronární tepny

Dýchání

latrogenní

Komplikace

Koronarografie

Perkutánní koronární intervence

Pravá koronární tepna

Keywords:

Complications

Coronary angiography

Coronary artery dissection

latrogenic

Percutaneous coronary

intervention

Respiration

Right coronary artery
SOUHRN

Disekce koronárních tepen při manipulaci s katétrem představuje poměrně vzácnou, nicméně potenciálně velmi závažnou komplikaci diagnostických a intervenčních výkonů na koronárních tepnách. Za možnou př́ičinu této komplikace bylo označeno několik rizikových faktorů, mezi něž patří hluboká intenzivní inhalace vedoucí ke změně polohy katétru a následně disekci koronární tepny. Předkládáme kazuistiku disekce pravé koronární tepny způsobenou změnou polohy katétru při fyziologickém vydechnutí. Pokud je mi známo, jedná se o první prípad, kdy se fyziologické vydechnutí podílelo na patofyziologii disekce koronární tepny prì manipulaci katétrem.

(c) 2019, ČKS

\section{ABSTRACT}

\begin{abstract}
Catheter-induced dissection of the coronary arteries is an uncommon but potentially dreadful complication of diagnostic and interventional coronary procedures. Several risk factors have been implicated in the development of this complication; one of them is deep vigorous inhalation inducing a change in catheter position thereby contributing to catheter-induced coronary artery dissection. The present article describes a case of catheter-induced right coronary artery dissection where a change in catheter position induced by active patient exhalation contributed to the development of dissection. To the best of my knowledge this is the first case implicating active exhalation in the pathophysiology of catheter-induced coronary artery dissection.
\end{abstract}

\section{Introduction}

Catheter-induced coronary artery dissection is an uncommon but well-described potentially dreadful complication of invasive coronary procedures. ${ }^{1-4}$ Inappropriate positioning of catheter tip in the coronary artery ostium has been reported as an important risk factor for this complication. ${ }^{1-4}$ The coronary arteries undergo displacement due to the cardiac systolic and diastolic motion and this displacement is greater than the displacement due to the respiratory motion during spontaneous respiration. ${ }^{5}$ Yet, active respiration entails larger coronary artery displacements, something that has practical importance during coronary angiography and intervention. When active respiratory movements are coordinated by the operator, the coronary artery displacement elicited, might facilitate catheter engagement and equipment navigation through the native coronary arteries and vein grafts during percutaneous coronary intervention $(\mathrm{PCl})^{6-8}$. Yet, even such a coordinated active respiratory activity might be hazardous, as in a case of catheter-induced left main coronary artery (LMCA) dissection where the patient's vigorous inhalation induced a change in catheter position thereby contributing to the complication [9]. The present case is one of a catheter-induced right coronary artery (RCA) dissection where a change in catheter position induced by active patient exhalation contributed to the development of the complication. To the best of my knowledge this is the first case implicating active exhalation in the pathophysiology of catheter-induced coronary artery dissection.

Address: Andreas Y. Andreou, MD, FESC, FACC, FSCAI, Department of Cardiology, Limassol General Hospital, Nikeas Street, Pano Polemidia, P0 Box 56060, 3304 Limassol, Cyprus, e-mail: y.andreas@yahoo.com DOI: 10.1016/j.crvasa.2018.06.001 


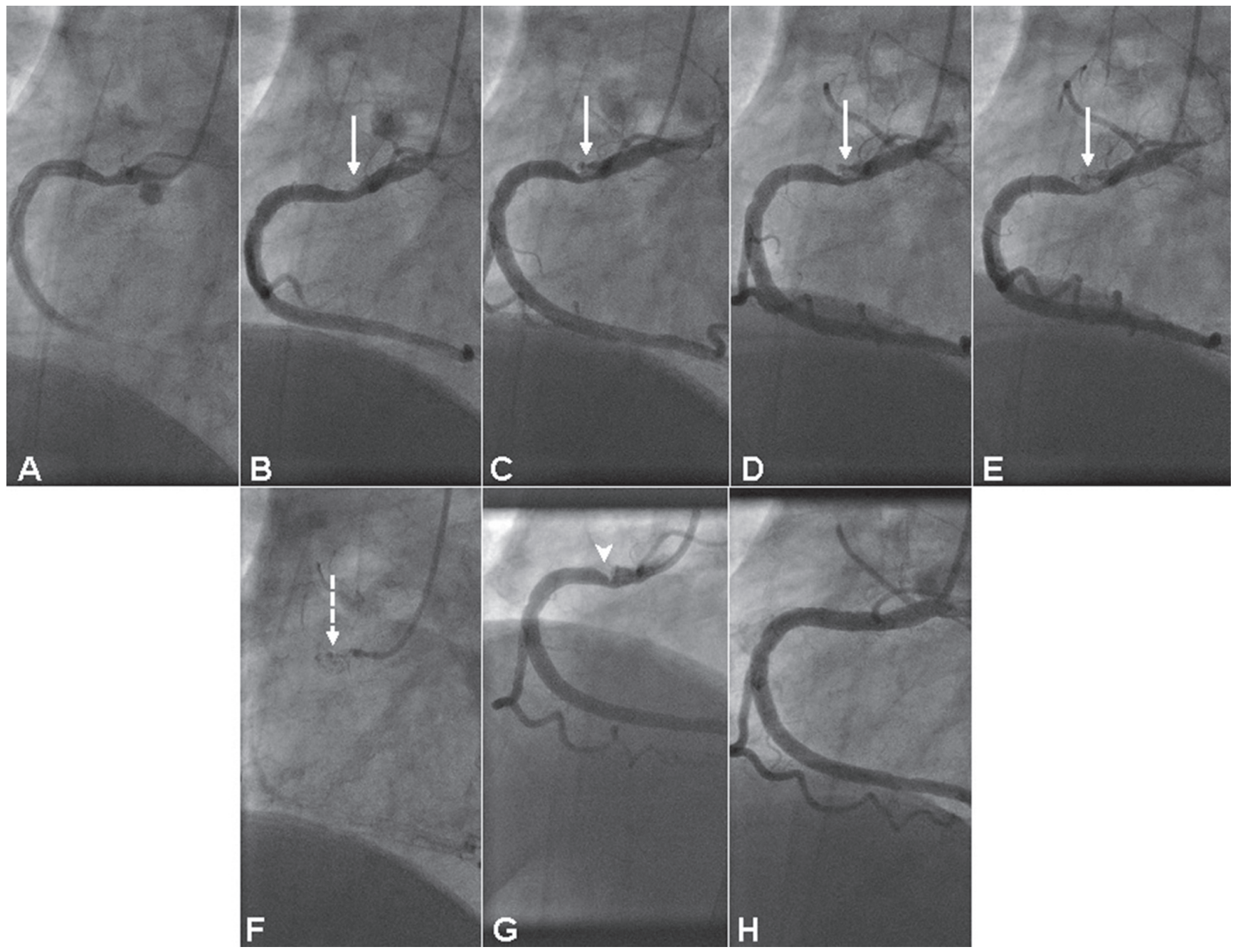

Fig. 1 - Angiograms of the right coronary artery (RCA). (A-E) Multiple frame illustration of RCA angiography in the left anterior oblique (LAO) projection. Note that from the beginning $(A)$ to the end $(E)$ of contrast medium injection, the diaphragm progressively ascends indicating the progress of exhalation. Meanwhile, the catheter becomes progressively deep-seated with resultant coronary plaque laceration and dissection of the adjacent vessel wall (arrow) starting at (B) and becoming more severe at (E). (F) Contrast-free image depicting persisting contrast dye staining (dashed arrow) at the site of vessel wall injury. (G) Angiographic presentation (LAO projection) of the iatrogenic proximal RCA lesion (arrowhead) immediately before percutaneous coronary intervention (PCI). (H) RCA angiogram (LAO projection) after PCl depicting an optimal result.

\section{Case presentation}

An 85-year-old male patient underwent right transradial coronary angiography because of atypical chest pain and moderate reversible ischemia of the apex and the apical anterior wall demonstrated on nuclear scintigraphy. This showed a total occlusion of the proximal left anterior descending (LAD) artery collateralized from a dominant RCA which contained a mild eccentric proximal stenosis. The RCA ostium was engaged coaxially with a 5 French Judkins right 4.0 catheter and after having confirmed a good catheter-tip pressure signal, we obtained an angiogram after gradual ramping of contrast medium injec- tion. However, shortly after the beginning of injection, the catheter became deep-seated and wedged against the vessel wall at the site of mild proximal stenosis with resultant hydraulic plaque laceration and vessel wall dissection during contrast medium injection (Fig. 1A-1F). Vessel patency was maintained and the patient had no chest pain or ischemic electrocardiographic abnormalities. The iatrogenic lesion (Fig. 1G) thus created was subsequently treated with implantation of a drug-eluting stent (Fig. $1 \mathrm{H})$. The patient tolerated the procedure well and was discharged in good condition. He was scheduled for percutaneous coronary intervention to the LAD artery. 


\section{Discussion}

latrogenic coronary artery dissection is a rare complication of invasive coronary procedures with a reported incidence rate of $0.034 \%$ during diagnostic coronary angiography. ${ }^{1}$ The RCA is the most frequently dissected vessel; the fact that the RCA originates almost perpendicular to the wall of the aortic sinus may render it more susceptible to catheter-induced dissection compared with the LMCA which originates at an acute angle and follows thereafter a course that is parallel to the wall of the aortic sinus thereby having a better approach for catheterization. This complication is mostly observed after inappropriate catheter tip positioning in the coronary artery ostium that is, not coaxial and/or deep catheter tip engagement. ${ }^{1-4}$ In such cases, dissection is the result of direct trauma to the coronary artery wall from the catheter tip and happens upon engagement of the coronary artery ostium; the catheter might be improperly sized and/or shaped or it might have been lunged into the artery with too great a force. Furthermore, dissection might be the result of trauma caused during contrast medium injection by the jet of contrast medium that is forcefully expelled from a catheter tip abutting on the coronary artery wall without necessarily causing pressure damping or ventricularization. The presence of atherosclerotic lesions in the coronary artery ostium has also been reported as a risk factor for catheter-induced dissection since an ostial plaque might be disrupted by the catheter tip upon coronary artery ostial engagement. ${ }^{1-4}$ Respiration-induced changes in the position of heart and therefore the position and course of coronary arteries have been reported to facilitate invasive coronary procedures. Deep inhalation displaces the diaphragm in a downward position and the heart in a downward and more vertical position whereas the ostia of the LMCA and RCA are displaced caudally and assume a more horizontal course for which reason breathholding in deep inhalation facilitates their engagement. ${ }^{5,6}$ Also, this maneuver has been reported to have a straightening effect on tortuous coronary arteries thereby facilitating balloon and stent delivery during $\mathrm{PCl}^{7}$ Similarly, breathholding in deep exhalation has been reported to result in straightening of tortuous vein grafts as the aorta and aortic arch where vein graft ostia are attached will be displaced upwards. ${ }^{8}$ Yet, respiration-induced changes in the position of the coronary artery ostia have been implicated in the pathogenesis of catheter-induced coronary artery dissection. To the best of our knowledge, the only relevant case thus far published referred to LMCA dissection caused by an Amplatz-shaped catheter during deep vigorous inhalation; ${ }^{9}$ the latter resulted in a caudal displacement of the LMCA ostium allowing deep seating of the catheter and impingement on the vessel wall thereby causing dissection as a result of direct trauma and/or trauma caused by the contrast medium jet expelled from the catheter tip which abutted the vessel wall. In the present case, the patient began to exhale upon commencement of contrast medium injection, thereby causing the origin of the RCA to move cranially and the catheter tip to move deep into the vessel and impinge on the eccentric proximal plaque. Contrast medium injection was therefore directed at the plaque - which might have already been disrupted by this catheter motion - thereby causing plaque laceration and dissection of the adjacent vessel wall. The dissection was localized and normal RCA blood flow was preserved whereas the patient had no evidence of myocardial ischemia. There has been reported a good outcome after conservative management in selected cases of catheter-induced coronary artery dissection causing no obstruction to flow or ischemia; ${ }^{4}$ however, cases of delayed progression of RCA dissection to complete occlusion have also been reported. ${ }^{10,11}$ In our patient, the RCA was dominant and also supplied a large area of myocardium to the LAD artery-dependent territory; thus in case of spontaneous extension of the dissection leading to abrupt vessel closure the patient would have sustained a large myocardial infarction. Accordingly, it was decided to mechanically stabilize the lesion with implantation of a drug-eluting stent, thereby averting the above-mentioned risk.

\section{Conclusion}

The present case illustrates the effect of exhalation on catheter position and how this change in catheter position contributed to catheter-induced RCA dissection. Besides optimal catheter selection, handling and engagement, paying attention to patient's respiratory activity and avoiding contrast media injection during active respiratory movements should be an additional precautionary measure taken during invasive coronary procedures in order to reduce the risk of catheter-induced coronary artery dissection.

\section{Conflict of interest}

None declared.

\section{Funding body}

None.

\section{Ethical statement}

I declare that the research was conducted according to Declaration of Helsinki.

\section{Informed consent}

I declare that informed consent requirements do not apply to this manuscript.

\section{Appendix A. Supplementary data}

Supplementary data associated with this article can be found in the online version.

\section{References}

1. Andreou AY, Avraamides PC, Andoniade $T$, et al. latrogenic left main coronary artery dissection: mind the catheter tip. Cardiovasc Med 2016;19:264-271.

2. Sanidas E, Buysschaert I, van Langenhove G. latrogenic left main coronary artery dissection and intramural hematoma caused by diagnostic transradial cardiac catheterization. Hellenic J Cardiol 2014;55:65-69.

3. Davlouros PA, Kontoprias K, Alexopoulos D. latrogenic left main coronary artery dissection mimicking complete proximal occlusion of the left main branches. Hellenic J Cardiol 2015;56:100-102.

4. Boyle AJ, Chan M, Dib J, Resar J. Catheter-induced coronary 
artery dissection: risk factors, prevention and management. J Invasive Cardiol 2006;18:500-503.

5. Shechter G, Resar JR, McVeigh ER. Displacement and Velocity of the Coronary Arteries: Cardiac and Respiratory Motion. IEEE Trans Med Imaging 2006;25:369-375.

6. Di Mario C, Sutaria N. Coronary angiography in the angioplasty era: projections with a meaning. Heart 2005;91:968-976.

7. Attaran RR, Butman S, Movahed MR. Going around the bend: deep inspiration facilitates difficult stent delivery in the native coronary arteries. Tex Heart Inst J 2011;38:270-274.

8. Movahed MR. Reverse Movahed Maneuver: Maximal Expiration Maneuver during Saphenous Vein Graft Intervention for Facilitated Balloon and Stent Delivery in Tortuous Vein Grafts A Novel Technique. Int J Angiol 2016;25 :e66-e69.
9. Biel SI, Krone RJ. Left coronary artery dissection with an amplatz-shaped catheter. The role of vigorous inspiration during contrast injection. Chest 1984;86:640-641.

10. Desai CK, Bhatnagar U, Stys A, Jonsson O. latrogenic propagation of coronary dissection during diagnostic coronary angiography: an uncommon but important procedural consideration. BMJ Case Rep 2017;2017:bcr2017222463.

11. Nagata $Y$, Maruyama M, Aburadani I, et al. A case of delayed occlusive dissection of the right coronary artery during coronary intervention of the left anterior descending artery. Cardiovasc Interv Ther 2015;30:155-161.

12. Eshaghy B, Bhalerao J, Croke RP, et al. Right coronary artery dissection. A complication of cardiac catheterization and coronary angiography. Chest 1976;70:551-553. 